\title{
Digital planning of the city of Barcelona and its relations with the strategic digital city
}

\author{
Eloisa Parteka ${ }^{1}$, Denis Alcides Rezende ${ }^{1^{*}}$
}

\begin{abstract}
The demand for new ways of managing cities requires faster, more technological and more digital means of interaction and communication. In this context, the strategic digital city applies the resources of information technology in municipal management, based on its strategies. The objective is to analyze the digital planning of the city of Barcelona and its relations with the strategic digital city. The methodology of the selected research is a unique case study in Barcelona, through the research protocol. The results obtained through the analyzes have shown that the digital planning of the city of Barcelona provides information technology and strategy resources that promote practices intrinsic to the strategic digital city, showing that the city of Barcelona applies these resources to the benefit of its inhabitants, making with which this city is increasingly democratic and digital. The analyzes demonstrate how digital planning can be aided by the strategic digital city project, confirming that the population would be increasingly benefiting from the technological and strategic resources. The conclusion reiterates that digital planning makes it possible to have an interface between the population, government and organizations in public passenger transport.
\end{abstract}

Keywords: Digital Planning; Strategic Digital City; Information Technology; Strategy

Submitted: August $30^{\text {th }}, 2018 /$ Approved: November $21^{\text {st }}, 2018$

\section{Introduction}

The demand for new ways of managing cities requires faster, more technological and more digital means of interaction and communication. In this context, the strategic digital city applies the resources of information technology in municipal management, based on its strategies. As such, technology is one of the indispensable factors for cities to keep pace with the transformation of society and meet the expectations and needs of the population (BOUSKELA et al., 2016).

Municipal planning can contribute to identify, understand and solve local problems, so government actions require planning as a continuous and ongoing process of prevention, management and control of urban management in order to promote the improvement of public services and the well- being of the population (REZENDE and FREY, 2005).

Therefore, strategic digital cities, according to Rezende (2012), apply the resources of information technology in municipal management, contributing and assisting with strategic, tactical and operational planning decisions; as well as study and make available information, systems and services to their managers and citizens.

The digital planning of the city of Barcelona has relations with the strategic digital city, as Barcelona has a network of citizen initiatives that use the technology available to organize and try to solve some of its needs, creating a more democratic and connected environment (MOBILE WORLD CAPITAL BARCELONA, 2016).

As far as the research problem is concerned, the technology has become necessary in the daily life of the population, but one of the problems is the need for urban policies that take care of the electronically excluded groups, since they may have access to the growing number of communities virtual urban spaces that have been created with the aim of citizens living in a new virtual public sphere. It is important to verify if technology really increases the capacity for participation and cooperation (LEMOS, 2005; SILVA, 2005).

The process of acculturation of information in municipalities can be facilitated and effective if citizens are interested in participating and using information technology, as well as managers in assuming the role of info managers (REZENDE, 2005). The State, in order to fulfill its function, must seek other new ways of having a more participative and democratic management (REZENDE; FREY, 2005). The problematization addressed is a consequence of the lack of integration among all institutional elements related to technology.

However, it is important to verify whether technology really enhances the ability to participate and cooperation, with the purpose of transforming these power relations. As such, they may have access to this growing number of virtual urban communities that have been created with the aim of conviviality among citizens in a new virtual public sphere (AURIGI, 2005; CASTELLS, 2003; SILVA, 2005).

Thus, it is necessary and increasingly urgent effective popular participation in the various dimensions of public policy decisions (SOUZA, REZENDE and HARDT, 2007), since, in order to fulfill its function, the State must seek new have a more participatory and democratic management. Thus, all this problematization dealt with is a consequence of the lack of integration between all institutional elements related to technology, citizens and governments (CASTELLS, 1999; REZENDE; FREY, 2005).

The main objective of this research is to analyze the digital planning of the city of Barcelona and its relations with the strategic digital city.

The research justifications strengthen that the public administration of cities are increasingly using digital platforms in their planning, as

(1) Pontifícia Universidade Católica do Paraná, Rua Imaculada. Conceição, 1155 - Prado Velho, Curitiba, PR - Brazil ${ }^{*}$ Corresponding author: denis.rezende@pucpr.br 
they provide greater efficiency, lower costs and more transparency in public services. With the use of technology, citizens can obtain more efficient information and services (LEITE; REZENDE, 2010).

The development of cities also occurs in order to obtain better communications (CASTELLS, 2006; GRAHAM; MARVIN, 1996). In this way, technology opens up new perspectives in cities and in the public space where users can interact and communicate AURIGI, 2005).

In order to analyze whether these considerations have occurred in the city of Barcelona, it was decided to analyze it, since this city is among the cities of the world that are closest to the materialization of the concept of Intelligent City (BOUSKELA et al., 2016, pp. 109). Barcelona was chosen in 2014 as the European Capital of Innovation, and its merits are recognized as a productive city, which improves its management through technology. The city also has a network of citizen initiatives that use available technology to organize and try to solve some of its needs, creating a more democratic and connected environment (MOBILE WORLD CAPITAL BARCELONA, 2016).

Technology, in the midst of a culture of generalized connection, enables forms of social mobility and appropriation of the urban space (CASTELLS, 2006; LEMOS, 2005).

A city becomes more efficient in that it is able to obtain data generated in the environment, in the installed infrastructures (by service providers) and in the buildings and streets (by the people), being able to process this data and transform it into information that allows to make decisions that can mitigate, organize, anticipate or anticipate innumerable urban challenges (BOUSKELA et al., 2016; CASTELLS, CARDOSO, 2005).

\section{Theoretical foundation}

\subsection{Digital planning of the city of Barcelona}

Cities, as well as the various segments of contemporary society, have undergone major transformations and transfigurations with the arrival of new technologies (SANTOS, 2014).

The old and new technologies are linked and, as a result, end up generating differentiated practices and a complex transformation in several areas of the city, such as urban planning and design. Technology makes possible the spatial transformation from its interventions in diverse scopes, such as the forms of spatial perception, experience, appropriation and planning. Global cultural and economic trends can be interconnected by the digital layers embedded in the physical space (GRAHAM, 2005).

As a result, the media are fundamental to inform society about all the issues, events and events that permeate the social and political milieu. For Polistchuck and Thirty (2003: 63), "communication is a human action whose purpose is to interpret events, to understand the facts of the world and to seek meaning for things". For this to occur, the Internet of Things (or Internet of Things) is required, which, according to Lemos (2013), is a set of networks, sensors and objects linked by computerized systems, which allow the expansion of communication between people and objects, having the ability to interconnect in an autonomous, automatic and context-sensitive way.

The citizen who uses a smartphone can be considered an urban sensor in real time and increasingly interested in getting involved in the affairs of the city. Once the information technology infrastructure in the cities is established, it becomes part of the urban fabric. Therefore, we need to add a layer of applications and communication systems that can function as interfaces between management and citizens and the different structures and departments of cities. Thus, these communication interface systems can serve as collaborative platforms, with the creation of mobile applications that allow data collection and participatory management by the citizen and also allow the city to communicate with users (BOUSKELA et al., 2016).

At the service of citizen participation, in many cities, the increasing use of digital platforms accessible via the web or via smartphones integrates the citizen in the various spheres of public administration, from the request of services to the monitoring of the accountability of municipal management. Barcelona provides ICT - Information Technology and communication to the vast majority of its citizens, incorporating services based on technology to improve city management and the relationship with citizens. With the final objective that the population of Barcelona can benefit from this "digital phenomenon" (MOBILE WORLD CAPITAL BARCELONA, 2016).

\subsection{Strategic digital city}

The strategic digital city (CDE) provides tools that improve the internal processes and public services provided to society (such as connectivity, information availability, technology, monitoring, infrastructure) that promote the participation of the population (REZENDE, 2012).

The technological and social changes of the information age, which created the conditions for its emergence, happened when the contemporary city established itself as a city-world in the post-industrial era, from the 70s and 80s (Lemos, 2005). Thus, it is possible to affirm that the technologies that favored the emergence of the digital city also led to the emergence of CDE.

On the other hand, Lévy (1999) reports that technology is a determinant, and not a determinant, of society and culture, since it itself is produced within a culture. On the other hand, technologies change the trajectory of social events, changing the local culture. From existing knowledge emerges technological innovation, which is a social phenomenon that begins with a local need, and then solve a universalized obstacle, according to Lévy (ibid.).

The technical literature of the area relates the digital city to the collection, structuring and provision of information by digital means so that citizens can interact with each other and with the government, interconnecting them in the digital network of a given territory. Consequently, this network can enable the integration of technological resources and can make public services and information available in different virtual realities of the urban space (REZENDE, 2012). 
Regardless of the difficulties encountered in implementing digital cities, they bring contributions to the government and citizens. Moutinho $(2010,79)$ reports that "despite obstacles and implementation difficulties, digital city projects have started an inexorable process of municipal modernization with positive effects on the quality of services and access to ICTs".

It can be observed that the concept of digital city and strategic digital city surpasses the universe of the Internet and its users, since it allows, in addition to access to the Internet, social and digital inclusion. However, even though the physical and digital infrastructure is important, the citizen needs to be involved and motivated in the processes of both the government and the municipality to benefit from the privileges that are made available. For this, it is important that the new technologies are disseminated to the citizen in order to arouse their interest and motivation (TANCMAN, 2004).

This scenario opens space for the emergence of the digital city as a system of intelligent and receptive places, saturated with programs and silicon, interconnected and interrelated (MITCHELL, 2001, p. Lemos (2004) also points out that the propagation of the technologies is given at very high speed with potential for infiltration and omnipresence, being able to act in a subtle and at the same time radical way in the spatial and cultural environment. Thus, people can play a very important role as beneficiaries and participants in these transformations through the active use of mobile devices and applications, which facilitate monitoring and collaboration with the policies of their rulers, according to Bouskela et al. (2016). It is possible to reach an advanced community model defined by Lemos (2004), in which the new ways of interacting with the environment materialize through information and communication technology.

2.3 Relationship between the digital planning of the city of Barcelona and the strategic digital city

The development and urban planning of cities are usually related to the needs of the population. Thus, technology and strategy become important factors to accompany the pace of transformation of society and consequently meet the needs of the population to relate to municipal decisions.

However, as was argued in previous chapters, government actions have been influenced by technologies and strategies, as these tools provide access to information. Being noticeable that the uses of these tools have become useful for a better relationship between citizens and rulers.

As a result, information technology is being used as a resource in city halls that allow the urban environment to become more and more connected with citizens. Thus, the growing use of information technologies in this context makes possible new forms of interactivity, becoming a more communicative medium, which opens up a range of new perspectives.

The digital planning of the city of Barcelona uses information technology and strategy, which are part of the CDE components. These are moderators so that users can take advantage of the technological benefits, contributing to digital inclusion. The technologies allow an increased capacity for interaction with the environment and, thus, the citizen is included in a physical and digital way in the context of the city.

Therefore, city management can be aided by the use of technologies and strategies, so that relations between citizens and city administrators become more effective. The relationships between strategy and information technology, which are part of the pillars of the CDE, help provide individuals with tools for improvement in cities.

\section{Research methodology}

The selected scientific method was the case study carried out in the city of Barcelona (SILVA; MENEZES, 2005; GIL, 2010; YIN, 2010).

As for the research techniques, the following procedures were used: bibliographical and descriptive survey for the bases of the theoretical foundation; the nature of the research instruments: qualitative method for the data collection in the city of Barcelona; qualitative approach to data and information analysis; identification and formulation of the problem; delimitation of the case unit to be studied; delimitation of the number of case studies; and formulation of the research protocol (SILVA; MENEZES, 2005).

The phases of the research clarified how the structures of the study project that were developed were prepared: preparation; data collection and analysis; documentation of results (GIL, 2010).

The survey, chosen for convenience (GIL, 2012) was Barcelona and took into account that this city has a network of initiatives that use the technology and the strategy to create a more democratic and connected environment. For this purpose, the content analysis of the sites was used as observation unit: ajuntamente.barcelona.cat; barcelona. cat; governmentbert.bcn.cat; which are relevant to the theme of this research (MARCONI and LAKATOS, 2010; YIN, 2010).

\section{Analysis of the digital planning of the city of Barcelona and its relations with the strategic digital city}

\subsection{Analysis of planning and the digital city}

The analysis of the digital planning of the city of Barcelona is based on the principle that both the $\mathrm{CDE}$ and the digital planning of the city of Barcelona have as one of their foundations the strategy and the information technology for the benefit of the citizens. The management of cities with the help of new technologies and strategies is a global trend, helping to make relations between citizens and city administrations easier and more transparent.

\section{a. Analysis of the digital planning of the city of Barcelona}

Barcelona is identified by intelligent management, able to respond quickly or even anticipated to the needs presented by its citizens (AJUNTAMENT DE BARCELONA, 2017).

The term "digital cities" has been used as a contemporary expression of an urban ideal that adds a better quality of life, information, communication and efficient management of services and pubic spaces. Thus, the use of strategies and information technologies serves as a 
platform to facilitate information and communication. Therefore, the digital city addresses the possibility of providing public services and information to citizens in broader virtual realities (REZENDE, 2012).

This intelligent management, in an attempt to improve the quality of life of citizens, has drawn up the "Barcelona City Digital 2017-2020" plan. This plan, presented in October 2016, is a municipal road map to promote the technological sovereignty of citizens, in order to allow a new model of urban innovation and promote a more pluralistic digital economy. It is based on the transformation and digital innovation of the public sector and of companies, government, universities, communities and organization of people with clear public leadership and citizen.

Figure 1 - Scheme of the Barcelona City Digital Plan 2017-2020

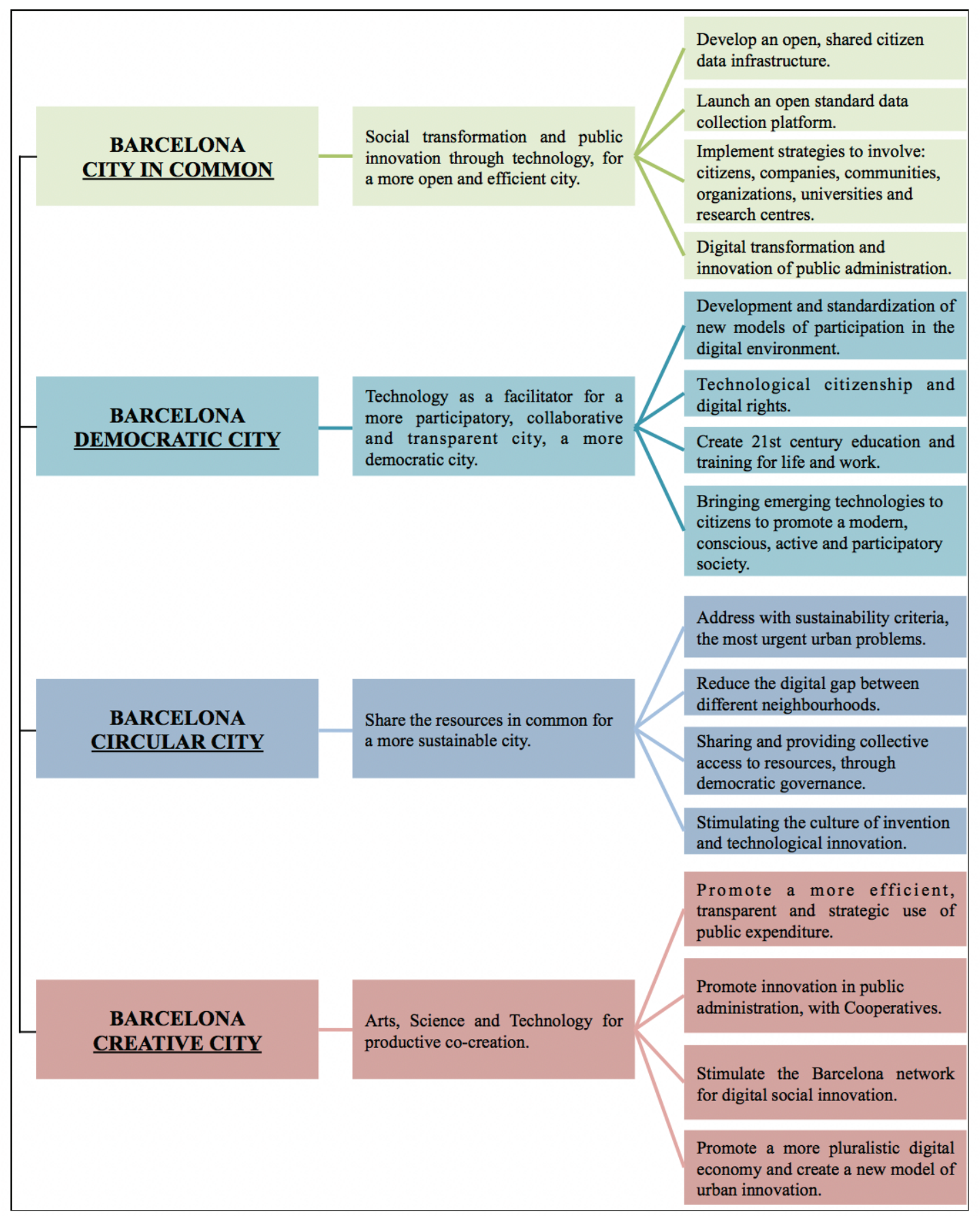

Source: the author (2017), based on data from the Ajuntament de Barcelona (2017). 
Consequently, Barcelona City Digital is based on four pillars, as shown in Figure 1, which are: Barcelona city in common, which deals with social transformation and public innovation through technology, for a more open and efficient city; Barcelona is a democratic city that focuses on technology as a facilitator for a more participatory, collaborative and transparent city, that is, for a more democratic city; Barcelona circular city, which raises the questions about sharing common resources for a more sustainable city; and Barcelona creative city, which points the questions about the arts, science and technology to productive co-creation.

The CDE is based on information technology, information, strategy and public services, which are the pillars of this concept, as shown in Figure 28. Thus, CDE provides tools that improve internal processes and public services provided to the society, such as connectivity, availability of information, technology, monitoring, infrastructure and the promotion of population participation. The CDE results in a series of benefits to the population, among which we can highlight the increase in the quality of life with the provision of services through the internet, through the participation of the citizen in the management of the city and the consequent contribution in the administration of the rulers (REZENDE, 2012). Therefore, the concept of CDE is related and can be identified in the Barcelona City Digital Plan 2017-2020.

\section{b. Analysis of information technology}

The Barcelona Digital City 2017-2020 plan is based on technology as a more accelerated means of social change and public innovation. This opens a range of new perspectives in cities and in the public space, since users can interact and communicate. Thus, technology enables beneficial transformations in physical and digital mobility (AURIGI, 2005). Thus, technologies change the trajectory of social events, changing the local culture from existing knowledge. In this way, technological innovation emerges, which is also social, starting with a local need and, in the end, solving a universalized social obstacle (LÉVY, 1999).

With the application of TIC, Barcelona Digital City intends to develop a data infrastructure of the city that is open and possible to be shared, as well as develop a strategy involving citizens, companies, communities and universities, with some well-defined policy lines democratization.

Technologies and therefore information technology are increasingly present in people's lives. Despite this, there is still a part that does not know or have not discovered the potential of these technologies and information technology, and it is possible to report that these people should not be aware of their rights in this area.

The municipal government of Barcelona has the ambition of increasing the digital domain of its citizens, allowing them both the possibility of having the digital and technological domain as the tools to be able to fully exercise their freedom and their digital rights. In order for Barcelona residents to achieve this technological sovereignty, the municipal government of this city has stimulated debates on this subject and tries to involve the interested parties. Thus, this government promotes open spaces for debates and opportunities for citizens to discuss and submit proposals on the city's technological strategy.

\section{c. Analysis of strategies}

The strategy can be understood as a means, a form, an activity or a way to meet the municipal objectives (REZENDE, 2012). The Barcelona City Digital Plan has the specific objective of improving the aspects of government and city; companies and social organizations; and citizenship. This plan aims at the agile and open transformation in the public administration. This digital transformation is a strategic project promoted by the Municipal Communication Institute, which aims to improve and streamline management processes and services for citizens, using information technology to benefit the inhabitants of Barcelona. To this end, the project includes the establishment of open standards for digital services and the optimization of strategic projects of the mandate of the current government, as well as their adaptation to the new framework and the regulation of digitization of the public sector. Including development, ensuring that TIC applications evolve appropriately to support all projects under this plan.

Nevertheless, the Barcelona Digital City Plan aims to provide, in a strategic and progressive way, all neighborhoods (districts) of the city infrastructure, resources, incentives and programs. In this way, each community, neighborhood or district can have resources available to enable citizens of all ages and conditions to make technology a means for improving public services and for more equitable and sustainable economic and social growth. As rapid changes in the social environment occur, it becomes evident the need for studies in the formulation of strategies, in the actions for decision-making and in the most effective solutions for city administration (OLIVEIRA, 2005). The strategy can be a standard or plan that integrates with the main goals, policies and sequences of action of the organization as a whole and, when well conceived, can contribute significantly (QUINN, 2006).

\section{Results between the digital planning of the city of Barce- lona and the digital city strategic}

The development and digital planning of Barcelona are related to technology and strategy in an intrinsic way. These became indispensable factors for this city to follow the pace of transformation of society. Thus, based on the previous analyzes of this research, it was possible to report how the relationship between the digital planning of the city of Barcelona and the strategic digital city happens.

The relationship between city strategies and information technology, which are part of the CDE concept, helps provide individuals with innovative tools for city improvements between rulers and citizens. Enabling an increased interaction capacity with the environment, since the citizen is now included in a physical and digital way in the context of the city, with digital inclusion, where users can enjoy the technological benefits.

Barcelona aims at the digital transformation of the city by using the technology of information through strategic projects, which aim to improve and streamline management processes and services to 
citizens, using information technology and strategy to benefit the inhabitants of Barcelona. Thus, information technology and, consequently, strategy are increasingly present in the lives of the people of this city. Nevertheless, the digital planning of the city of Barcelona is close to the concept of $\mathrm{CDE}$, since both this planning and the $\mathrm{CDE}$ have as one of its foundations the strategy and the information technology for the benefit of the citizens. The management of the city is aided by the use of technologies and strategies, and this is a worldwide trend, so that relations between citizens and city administrators become more transparent and effective.

\section{Conclusion}

Through this research, it was possible to verify that the digital planning of the city of Barcelona is used in this city effectively, because it is possible to recognize that the strategy and the information technology make possible the interface between the population and the government. It is clear that the Barcelona government prioritizes information and communication issues in city planning. Physical and digital displacement becomes more and more important in this scenario. It was also possible to perceive that the information technologies make possible the spatial transformation from their interventions in the urban environment. However, it was possible to note that this city owns and uses the four pillars of the CDE concept, which are information technology, information, services and strategy, as a means to meet the municipal objectives.

The objective was achieved insofar as the analysis of the digital planning of the city of Barcelona and its relations with the strategic digital city was elaborated.

The results obtained through the analyzes have shown that the digital planning of the city of Barcelona provides information technology and strategy resources that promote practices intrinsic to the strategic digital city, showing that the city of Barcelona applies these resources to the benefit of its inhabitants, making with which this city is increasingly democratic and digital. The analyzes demonstrate how digital planning can be aided by the strategic digital city project, confirming that the population would be increasingly benefiting from the technological and strategic resources.

The present research opens space for managers and citizens of Brazilian cities to also reflect on the use of information technology and strategy in the management of municipalities. In this way, people can realize that it is possible to use as an example the way in which the management and the citizens of Barcelona make use of these tools of information technology and the strategy for the own benefit. The research presents some limitations, as far as the methodological procedures used, one of the limitations of this research is the use of a single case study, so that the results obtained in this research cannot be generalized to other cities.

The research, besides contributing with the studied city, Barcelona, can also contribute with other cities, since the analysis can be configured as a source of consultation so that other cities make a self-evaluation of the use of information technologies and the strategy in the municipal system. These tools are used to work with the concerns and the changing conditions surrounding municipal governments being addressed within the concept of strategic digital city with the intention of transforming ordinary citizens into digital citizens. Reiterating that a city is better managed as it is well planned, increasing the quality of life of its citizens and enabling the interface between the population and the government, as the case studied.

Acknowledgments: CNPq Brasil (Productivity research scholarship).

\section{Referencias}

AJUNTAMENT de Barcelona. Barcelona Digital City (2017) Retrieved from https://ajuntament.barcelona.cat/digital/en

AURIGI, A. (2005). Making the Digital City: the early shaping of urban internet space. Hampshire: Ashgate.

BOUSKELA, M. et al. (2016). Caminho para as Smart Cities: da gestão tradicional para a Cidade Inteligente. Banco Interamericano de Desenvolvimento.

CASTELLS, M. (2003). A galáxia da internet: reflexões sobre a internet, os negóciose a sociedade. Rio de Janeiro: Jorge Zahar.

CASTELLS, M. (1999). A sociedade em rede. São Paulo: Paz e Terra.

CASTELLS, M. (2006). A questão urbana. 3. ed. São Paulo: Paz e Terra.

CASTELLS, M.; CARDOSO, G. (2005). A sociedade em rede: do conhecimento à

ação política. Belém: Imprensa Nacional.

GIL, A. C. (2010). Como elaborar projetos de pesquisa. 5. ed. São Paulo: Atlas.

GIL, A. C. (2012). Métodos e técnicas de pesquisa social. 6. ed. São Paulo: Atlas.

GRAHAM, S.; MARVIN, S. (1996). Telecommunications and the City: Electronic Spaces, Urban Places. London: Routledge.

LEITE, L. de O.; REZENDE, D. A. (jul./dez. 2010) Realizando a gestão de relacionamentos com os cidadãos: proposição e avaliação de um modelo baseado no Citizen Relationship Management. Urbe: Revista Brasileira de Gestão Urbana, Curitiba, v. 2, n. 2, p. 247-258.

LEMOS, A. (2013). A comunicação das coisas: teoria ator-rede e cibercultura. São Paulo: Annablume.

LEMOS, A. (2004). Cibercultura, tecnologia e vida social na cultura contemporânea. 2. ed. Porto Alegre: Sulina.

LEMOS, A. (2005). Cidade-ciborgue: a cidade na cibercultura. In: (Org.). Cibercidade II: Ciberurbe - A cidade na sociedade da informação. 1. ed. Rio de Janeiro: E-Papers. 
MARCONI, M. A.; LAKATOS, E. M. (2010). Fundamentos de metodologia científica. 7. ed. São Paulo: Atlas.

MEIRELES, M. (2014). Sistemas de informação: quesitos de excelência dos sistemas de informação operativos e estratégicos. Vol. 1. Série Indicadores Gerenciais. São Paulo: Arte \& Ciência.

MITCHELL, W. J. (2001). E-topía: vida urbana, Jim, pero no la que nosotros conocemos. Barcelona: G. Gili.

MOBILE World Capital Barcelona. La brecha digital en la ciudad de Barcelona (2016). Retrieved from https://www.mobileworldcapital. com/escletxa-digital

OLIVEIRA, D. P. R. (2005). Sistemas de informações gerenciais: estratégias, táticas operacionais. 8. ed. São Paulo: Atlas.

POLISTCHUCK, I.; TRINTA, A. R. (2003). Teorias da comunicação: o pensamento e a prática do jornalismo. Rio de Janeiro: Campus, 2003.

REZENDE, D. A. (2012) Planejamento de estratégias e informações municipais para cidade digital: guia para projetos em prefeituras e organizações públicas. São Paulo: Atlas.
REZENDE, D. A.; FREY, K. (apr./jun 2005). Administração estratégica e governança eletrônica na gestão urbana. Revista Eletrônica de Gestão de Negócios (eGestão), v. 1, n. 1, p. 51-59.

SANTOS, M. (2014). A natureza do espaço: técnica e tempo, razão e emoção. São Paulo: EDUSP.

SANTOS, A. R. dos. (2002). Metodologia científica: a construção do conhecimento. 5. ed. Rio de Janeiro: DP\&A.

SILVA, S. P. (oct, 2005). Graus de participação democrática no uso da internet pelos governos das capitais brasileiras. Revista Opinião Pública, Campinas, v. 11, n. 2, p. 450-468.

SILVA, E. L. da; MENEZES, E. M. (2005). Metodologia da pesquisa e elaboração de dissertação. 4. ed.. Florianópolis: UFSC, 138 p.

YIN, R. K. (2010). Estudo de caso: planejamento e métodos. 4. ed. Traduction de Ana Thorell. São Paulo: Bookman, 248p. 